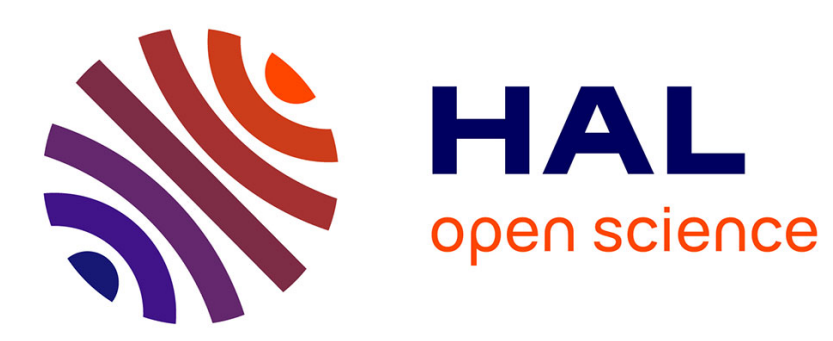

\title{
Low-shrinkage refractories bonded with high-alumina cement mixed with colloidal silica
}

\author{
N. Richard, N. Lequeux, P. Boch
}

\section{To cite this version:}

N. Richard, N. Lequeux, P. Boch. Low-shrinkage refractories bonded with high-alumina cement mixed with colloidal silica. Journal de Physique IV Proceedings, 1993, 03 (C7), pp.C7-1403-C7-1406. 10.1051/jp4:19937215 . jpa-00251850

\section{HAL Id: jpa-00251850 https://hal.science/jpa-00251850}

Submitted on 1 Jan 1993

HAL is a multi-disciplinary open access archive for the deposit and dissemination of scientific research documents, whether they are published or not. The documents may come from teaching and research institutions in France or abroad, or from public or private research centers.
L'archive ouverte pluridisciplinaire HAL, est destinée au dépôt et à la diffusion de documents scientifiques de niveau recherche, publiés ou non, émanant des établissements d'enseignement et de recherche français ou étrangers, des laboratoires publics ou privés. 


\title{
Low-shrinkage refractories bonded with high-alumina cement mixed with colloidal silica
}

\author{
N. RICHARD, N. LEQUEUX and P. BOCH
}

Laboratoire Céramiques et Matériaux Minéraux, UA-CNRS, Matériaux Inorganiques, ESPCI, 10 rue Vauquelin, 75005 Paris, France

\begin{abstract}
Low-shrinkage refractories were prepared by bonding ceramic grains with high-alumina cement mixed with colloidal silica. The phases formed during hydration or heat treatment were studied by $\mathrm{XRD}$ and IR-spectroscopy. The main hydrated phases were $\mathrm{CaO}-\mathrm{Al}_{2} \mathrm{O}_{3}-10 \mathrm{H}_{2} \mathrm{O}$ (hydration at $20^{\circ} \mathrm{C}$ ) and $3 \mathrm{CaO}-\mathrm{Al}_{2} \mathrm{O}_{3}-6 \mathrm{H}_{2} \mathrm{O}$ plus $2 \mathrm{CaO}-\mathrm{Al}_{2} \mathrm{O}_{3}-\mathrm{SiO}_{2}-8 \mathrm{H}_{2} \mathrm{O}$ (hydration at $50^{\circ} \mathrm{C}$ ). $12 \mathrm{CaO}-7 \mathrm{Al}_{2} \mathrm{O}_{3}$ was the first phase that crystallised during thermal treatments. At $\mathrm{T}>1000^{\circ} \mathrm{C}, 12 \mathrm{CaO}-7 \mathrm{Al}_{2} \mathrm{O}_{3}$ reacts with silica to form anorthite $\left(\mathrm{CaO}-\mathrm{Al}_{2} \mathrm{O}_{3}-2 \mathrm{SiO}_{2}\right)$ and gehlenite $\left(2 \mathrm{CaO}-\mathrm{Al}_{2} \mathrm{O}_{3}-\mathrm{SiO}_{2}\right)$. Part of colloidal silica combines with calcium and aluminum to form cristobalite, which is stabilised in its $\beta$ -form. Shrinkage was measured by dilatometry. The crystallisation phenomena are beneficial to reduce firing shrinkage. The stabilisation of $\beta$-cristobalite eliminates the dilatometric anomaly usually induced by the $\beta \leftrightarrow \alpha$ transformation at $\approx 200^{\circ} \mathrm{C}$.
\end{abstract}

\section{Introduction}

A near-zero shrinkage is required when processing refractory casting moulds, which must be very accurate in shape and size. Most of ceramic moulds are made by sintering a mixture of ceramic grains (for example, zircon and vitreous silica) with a silica gel. Consolidation is due to the viscous flow of amorphous silica, which allows the formation of necks between ceramic grains. Densification and, therefore, shrinkage are limited by phenomena associated with the recrystallisation of silica to cristobalite.

Although high-alumina cements (HAC) are frequently used to prepare castable refractories, they are rarely employed to prepare foundry moulds. The present study was devoted to the preparation of lowshrinkage refractories bonded with HAC mixed with colloidal silica.

\section{Experimental}

The filler materials were vitreous silica $\left(\mathrm{d}_{50}=24 \mu \mathrm{m}\right)$ and zircon $\left(\mathrm{d}_{50}=12 \mu \mathrm{m}\right)$. The bonding materials were prepared from a mixture of HAC (SECAR 71 - Lafarge Fondu International) with colloidal silica (LUDOX AS40 - Du Pont de Nemours). The main phases in SECAR 71 are calcium aluminates $\mathrm{CA}$ and $\mathrm{CA}_{2}$ and $\alpha$-alumina $\left(\mathrm{C}=\mathrm{CaO}, \mathrm{A}=\mathrm{Al}_{2} \mathrm{O}_{3}, \mathrm{~S}=\mathrm{SiO}_{2}, \mathrm{H}=\mathrm{H}_{2} \mathrm{O}\right) . L U D O X$ AS40 is an aqueous colloidal dispersion $(40 \mathrm{wt} \%)$ of silica particles (average diameter $=22 \mathrm{~nm}$ ).

The compositions of the various refractories are given in table I. Filler-free samples, labelled as "Cement $A^{\prime \prime}$ and "Cement B", were also prepared to study the chemical reactions of bonding materials during hydration and firing. It was verified that those reactions were only slightly affected by the nature of filler.

HAC and deflocculated colloidal silica were mixed together to prepare the cement pastes. After mixing, the pastes were placed in glass tubes that were sealed and soaked at $20^{\circ} \mathrm{C}$ or $50^{\circ} \mathrm{C}$. Curing times 
ranging from 2 hours to 7 days were chosen to study hydration. Hydration was stopped prior to XRD measurements by washing the crushed paste with acetone. Acetone was subsequently removed using ether.

Refractories were prepared by mixing the dry powders first, then adding LUDOX $A S 40$. Green mixtures were cast into open moulds $\left(10 \times 10 \times 30 \mathrm{~mm}^{3}\right)$, then soaked at $50^{\circ} \mathrm{C}$ for 7 days in water-saturated air. Heat treatments were done by firing materials at $3^{\circ} \mathrm{C} \cdot \mathrm{min}^{-1}$ to temperatures ranging from $400^{\circ} \mathrm{C}$ to $1350^{\circ} \mathrm{C}$

Chemical reactions during hydration and phase evolution due to thermal treatments were investigated by XRD (Philips 1710, $\mathrm{Cu}-\mathrm{K} \alpha$ radiation) and IR spectroscopy (Perkin-Elmer 1600 series, FTIR). The highest X-ray peak intensity for each phase was plotted vs. curing and firing conditions. The corundum in excess in HAC and a silicon powder mixed with the materials crushed after firing were used as internal references for the $\mathrm{X}$-ray analysis of hydrates and high-temperature phases, respectively. Shrinkage of materials was measured using an absolute dilatometer (Enter labs., model 1161), working at a heating rate of $3^{\circ} \mathrm{C} \cdot \mathrm{min}^{-1}$

Table I.

Composition of cements (wt\%)

\begin{tabular}{ccc}
\hline Series & A & B \\
\hline HAC & 13 & 67 \\
Colloidal silica & 87 & 33 \\
Water/HAC ratio & 9.7 & 0.75
\end{tabular}

Composition of castables (wt\%)

\begin{tabular}{cccc}
\hline Series & A & B & C \\
\hline Filler* & 85 & 85 & 85 \\
Cement A & 15 & & \\
$\begin{array}{c}\text { Cement B } \\
\text { Colloidal silica }\end{array}$ & & 15 & 15 \\
* 25 wt\% $\mathrm{ZrSiO}_{4}+75$ wt\% a-SiO & \\
\end{tabular}

\section{Hydration}

Hydrated phases were found to develop according to the usual scheme:

$20^{\circ} \mathrm{C}: \mathrm{CAH}_{10}$ is the main crystallised hydrate and $\mathrm{CA}$ is consumed faster than $\mathrm{CA}_{2}$, which cannot convert to $\mathrm{CAH}_{10}[1]$.

$50^{\circ} \mathrm{C}: \mathrm{C}_{2} \mathrm{AH}_{8}$ forms first, then rapidly converts to hydrogarnet $\mathrm{C}_{3} \mathrm{AH}_{6}$ and gibbsite $\mathrm{AH}_{3}$. The reaction between silica and cement leads to the formation of stratlingite $\mathrm{C}_{2} \mathrm{ASH}_{8}$

Stratlingite is considered to have a beneficial influence on mechanical strength of HAC [2]. It is one of the reasons why many studies have been devoted to the incorporation of fume silica into HAC for the fabrication of castable refractories [3]. Our experiments (not reported here) have shown that stratlingite develops more easily when silica is in the form of a colloidal gel than when it is as fume, which must be due to the much higher specific surface area of the former than of the latter $\left(\mathrm{Sp}=220 \mathrm{~m}^{2} \cdot \mathrm{g}^{-1}\right.$ and $14 \mathrm{~m}^{2} \cdot \mathrm{g}^{-1}$ for AS40 and fume silica, respectively). This explains the choice of a colloidal gel.
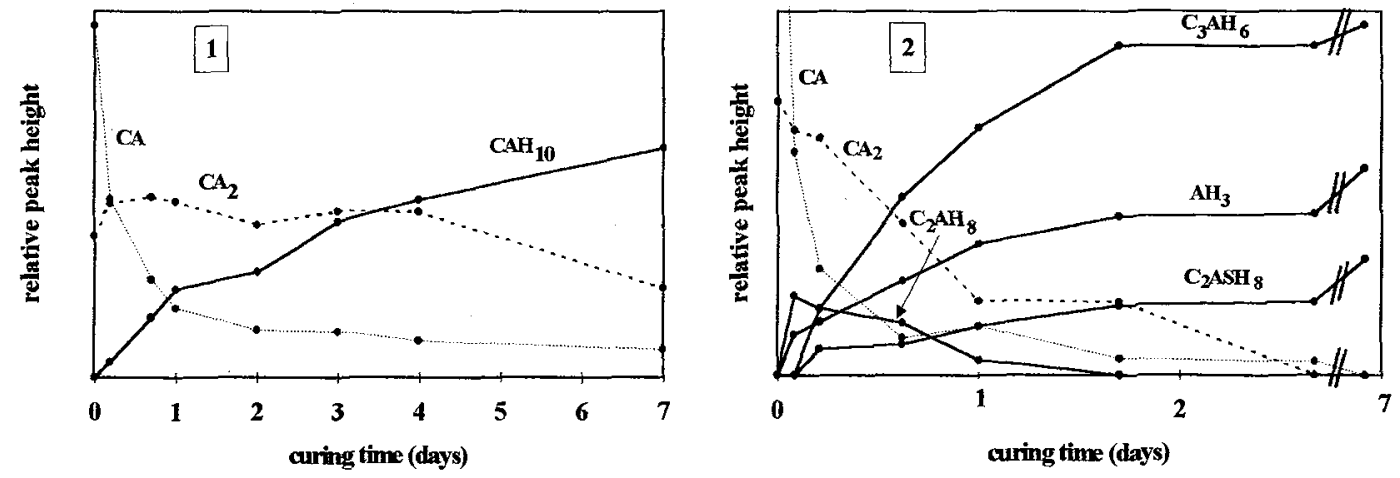

Fig. 1.Hydrated phases in cement B vs. curing time: at $20^{\circ} \mathrm{C}$ (graph 1) and $50^{\circ} \mathrm{C}$ (graph 2). 


\section{Firing}

\section{- Cement A}

The main crystallised phases are constituted of various forms of silica, which were identified using both XRD and IR-spectroscopy.

$\beta$-cristobalite is first observed after a heat treatment at $1100^{\circ} \mathrm{C}$. Upon cooling, $\beta$-cristobalite should normally transform into its $\alpha$-form (reversible transformation between $180^{\circ}$ and $270^{\circ} \mathrm{C}$ ). However, this transformation was not observed, which shows that $\beta$-cristobalite is conserved down to room temperature. This stabilisation can be explained by the incorporation of foreign ions $\left(\mathrm{Ca}^{2+}\right.$ in the present case) in the interstices of the cristobalite structure, with a charge compensation by the substitution of $\mathrm{Al}^{3+}$ for $\mathrm{Si}^{4+}$ in the Si-O framework [4].

When the firing temperature is raised above $1250^{\circ} \mathrm{C}, \beta$-cristobalite progressively disappears in favor of $\alpha$-cristobalite. One can notice the presence of quartz as a minor phase after firing at $1175^{\circ} \mathrm{C}$.

\section{- Cement $B$}

The thermodynamically stable phases anorthite $\left(\mathrm{CAS}_{2}\right)$ and gehlenite $\left(\mathrm{C}_{2} \mathrm{AS}\right)$ are found after firing above $1400^{\circ} \mathrm{C} . \mathrm{C}_{12} \mathrm{~A}_{7}$ and $\beta$-cristobalite exist at intermediate temperatures of firing.

Neither the nature nor the relative content of the high-temperature phases appear to be sensitive to the nature of the hydrates and, therefore, to the value of the curing temperature $\left(20^{\circ} \mathrm{C}\right.$ or $\left.50^{\circ} \mathrm{C}\right)$.
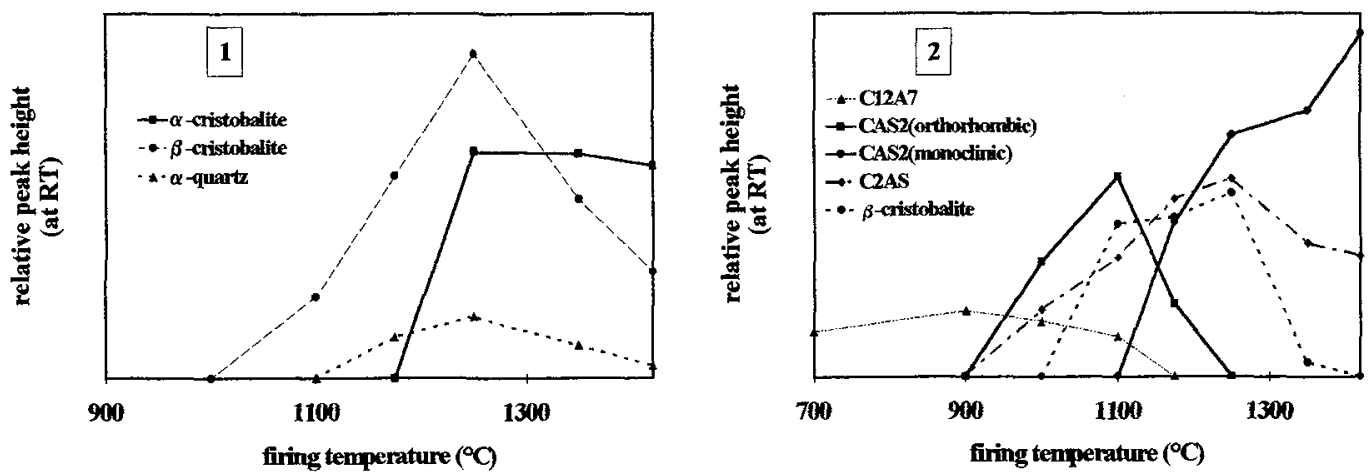

Fig.2. Phases in cementitious mixtures (cure of 7 days) vs. firing temperature: cement $\mathrm{A}$ (graph 1) and cement B (graph 2).

\section{Expansion behaviour}

Figure 3 shows curves of shrinkage vs. temperature, for three materials.

\section{- Castable C}

There is a noticeable shrinkage between $1000^{\circ} \mathrm{C}$ and $1250^{\circ} \mathrm{C}$, which must be due to the viscous flow of the vitreous colloidal silica used as bonding material.

\section{- Castables $A$ and $B$}

Shrinkage decreases when the cement content increases $\left(\Delta l / l_{1400^{\circ} \mathrm{C}}=-3.6 \%,-2.7 \%\right.$, and $-0.7 \%$ for castables $\mathrm{C}, \mathrm{A}$, and $\mathrm{B}$, respectively). It is

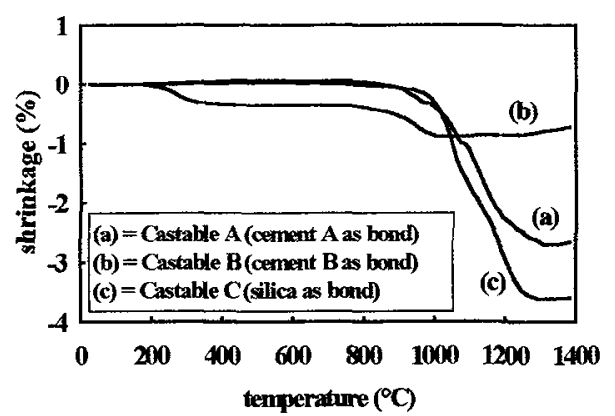

Fig.3. Shrinkage of refractories 
thought that the devitrification of colloidal silica, whose temperature decreases when cement is added (from $1250^{\circ} \mathrm{C}$ to $1100^{\circ} \mathrm{C}$ ), limits the viscous flow and, therefore, limits the shrinkage. For castable $\mathrm{B}$, an additional effect can also be due to the presence of crystallised phases such as $C_{2} A S, C A S_{2}$ or $C_{12} A_{7}$.

The shrinkage of about $-0.3 \%$, observed between 200 and $300^{\circ} \mathrm{C}$ for castable $\mathrm{B}$, is correlated to the dehydration of HAC, as verified by TGA experiments (not represented here).

The room-temperature stabilisation of $\beta$-cristobalite in castables fired between $1100^{\circ} \mathrm{C}$ and $1250^{\circ} \mathrm{C}$ allows a dramatic decrease in the dimensional changes, by suppression of the $\beta \leftrightarrow \alpha$ transformation (fig. 4).

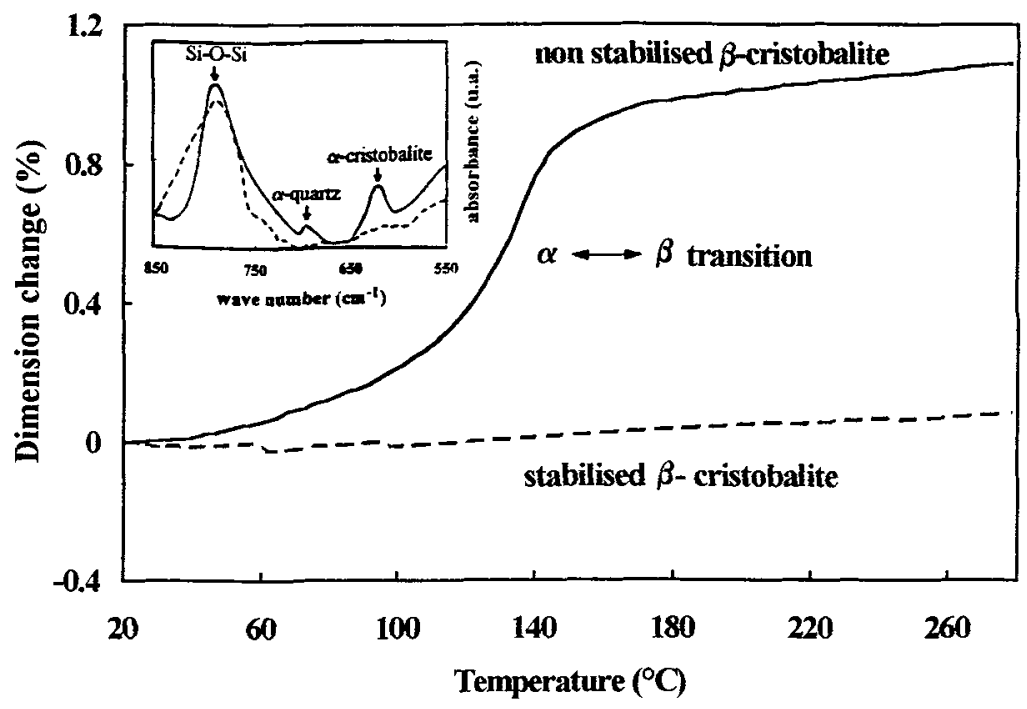

Fig 4. Thermal expansion of castable A ( $87 \%$ silica $+13 \% \mathrm{HAC})$ fired at $1100^{\circ} \mathrm{C}$ (dashed line) and $1350^{\circ} \mathrm{C}$ (continuous line). Inset: IR spectra.

\section{Conclusion}

Cementitious compositions made of a high-alumina cement mixed with a colloidal silica gel can be used as bonding materials in silica-based refractories. This leads to a dramatic reduction in shrinkage, which can be due to three causes: i) a decrease in the recrystallisation temperature of amorphous silica, ii) the cristallisation of $\mathrm{CAS}_{2}$ and $\mathrm{C}_{2} \mathrm{AS}$, and iii) the stabilisation of $\beta$-cristobalite and, therefore, the suppression of the $\beta \leftrightarrow \alpha$ transformation. As a consequence, those refractories offer potential in foundry-mould applications, where a high dimensional accuracy is a main requirement.

\section{References}

[1] BENTSEN S., SELTVEIT A., and SANDBERG B., 294-319, Calcium aluminate cements, Spon Publ., London (1990).

[2] MIDGLEY H.G., and BHASKARA RAO P., Cem. Concr.Res. 8 (1978) 169-172.

[3] CLAVAUD B., MARJERRISON J., and HEATHCOTE P., British Ceram. Soc., 7 (1985) 2-5.

[4] SALTZBERG M.A., BORS S.L., BERGNA H., and WINCHESTER S.C., J. Am. Ceram. Soc. 75 (1992) 89-95. 